удк 005.336.4:330.341.1

DOI https://doi.org/10.32851/2708-0366/2020.4.16

Ціпуринда В.C.

кандидат економічних наук, доцент,

Київський національний торговельно-економічний університет

Підкамінний I.M.

кандидат економічних наук, доцент, Київський національний торговельно-економічний університет

Tsipurinda Vladimir, Pidkaminniy Igor Kyiv National University of Trade and Economics

\title{
ІННОВАЦІЙНИЙ ПІДХІД ДО ВИЗНАЧЕННЯ ПРІОРИТЕТІВ ТА ІНСТРУМЕНТІВ КАДРОВОГО МЕНЕДЖМЕНТУ У РОЗВИТКУ ПІДПРИЄМСТВА
}

\section{INNOVATIVE APPROACH TO DEFINITION OF PRIORITIES AND INSTRUMENTS OF HUMAN RESOURCES MANAGEMENT IN THE DEVELOPMENT OF THE ENTERPRISE}

У статті досліджено інновачійний підхід до визначення пріоритетів та інструментів кадрового менеджменту в інноваційному розвитку підприємства та проаналізовано його сучасні завдання й роль для організування безперервного прочесу нарошування конкурентних переваг у всіх напрямах ресурсного забезпечення, впровадження нововведень. Запропоновано інноваційний підхід до комплексного розуміння та вирішення проблем підготовки керівних кадрів у системі управління та самоуправління для розвитку підприємства як відкритої системи, шо взаємоузгоджено розвивається в сучасних умовах, а також пов'язані з цим комплексні завдання як упорядкованої специфічної сфери, яка націлена на вирішення певних завдань упровадження інноваційних технологій у систему управління кожною соціально-економічною системою, зокрема вирощування лідерів для розвитку суспільства.

Ключові слова: інновачійний підхід, інновації, кадри, система, управління, самоуправління, відкрита система, взаємоузгоджений розвиток, упорядкування, інновачійні технологіi, професіоналізм, закони природи.

В статье исследован инновационный поход к определению приоритетов и инструментов кадрового менеджмента в инновационном развитии предприятия и проанализированы его современные задания и роль для организации беспрерывного процесса наращивания конкурентных преимуществ во всех направлениях ресурсного обеспечения, внедрения нововведений. Предложен инновационный подход к комплексному пониманию и решению проблем подготовки руководящих кадров в системе управления и самоуправления для развития предприятия как открытой системыл, которая взаимосогласованно развивается в современных условиях, а также связанные с этим комплексные задания как упорядоченной специфической сферы, которая нацелена на решение определенных заданий внедрения инновационных технологий в систему управления каждой соииально-экономической системой, в частности выращивание лидеров для развития общества.

Ключевые слова: инновационный поход, инновации, кадры, система, управление, самоуправление, открытая система, взаимосогласованное развитие, упорядочивание, инновационные технологии, профессионализм, законы природы.

In the article the innovative going is offered near the complex understanding of problems of training of leading personnel's in control system and self-government for development of enterprise as open system, that concertedly develops in modern terms, and also complex tasks are related to it, as a well-organized specific sphere that is aimed at the decision of set tasks of introduction of innovative technologies in control system by every socio-economic system, in thereby and by an enterprise and for development of society. The innovative going is investigational near determination of priorities and instruments of skilled management in 
innovative development of enterprise and he is analyzed modern tasks and role for organization of continuous process of increase of competitive edges in all directions of the resource providing, introduction of innovations taking into account the concordance of development of all forms of vital functions, id est systems of different level, that must be built on the basis of the Natural laws, taking into account basic primary 3 parameters of their development: space, time and energy. According to it, in the dynamics of development of the systems evidently, that consistently corresponding styles (stages) of management: give birth authoritarian that related to dictatorship of legislator or employer (1 th law), democratic (2th law), that related to delegation of part of the plenary powers by a leader. And as soon as there are the general concerted actions, the 3th stage of management comes - liberal (3th law). Thus, by major priorities and instruments of further development of the socio-economic systems, including enterprises, there is a concordance of internal and external processes, where a prominent role is occupied by creative development of man, as primary basis of all other systems. For this purpose must be ranged system, incremental and complex preparation of leader, that embraces management experience not only productive but also management the social and territorial systems and associations, must be adjusted for this purpose. And it can be basis of experience for successful guidance outside an enterprise, for example in the management of territorial communities or systems of social character. The system of triple repetition of management experience, both at the grassroots level and at the level of society, is solved by repetition of 4 basic functions of management: planning, organizing, motivating and controlling. Therefore, a gradual combination of triple-concerted experience of strategic, tactical and operational types of planning, organizing, motivating and controlling with regulation aims to achieve an ideal management cycle in 12 stages, determinants.

Key words: innovative hike, innovations, shots, system, management, self-government, open system, concertedly development, arrangement, innovative technologists, professionalism, natural laws.

Постановка проблеми. Сучасні умови економічного розвитку ставлять перед його ініціаторами завдання організування безперервного процесу нарощування конкурентних переваг у всіх напрямах ресурсного забезпечення, впровадження нововведень та відповідної гнучкої системи управління, яка стимулює розвиток, зокрема розвиток системи підготовки керівних кадрів. Постійне розширення матеріальних та духовних потреб людини на всіх рівнях потребує постійного розширення ресурсів, які обмежені у планетарному масштабі. Загальновідомо, що тут криється головна проблема світового розвитку, зокрема розвитку технології менеджменту, оскільки світові соціально-економічні кризи все більше зростають і за своєю глобальністю, і за частотою повторення.

Головним джерелом розвитку сьогодні, окрім технічних, технологічних та фінансових ресурсів, є система так званих нематеріальних активів, перш за все людські ресурси, професіоналізм і знання керівного складу підприємства й держави як упорядкована специфічна сфера, яка націлена на вирішення певних завдань впровадження інноваційних технологій у системі управління кожною соціально-економічною системою, зокрема підприємством. Однак, незважаючи на постійне зростання загального інтелектуального потенціалу як суспільства, так і керівного складу кожного підприємства, наявний стан менеджменту призводить до криз, зокрема соціально-економічних, екологічних.

Отже, у сучасному менеджменті особливо важливо побачити місце й роль кожної людини в управлінні як підприємством, так і розвитком суспільства як взаємоузгоджених систем. Для цього недостатньо тільки професійних знань сучасного менеджменту, потрібно поєднати з ними загальні знання про дію діалектичних законів природи, що дає змогу прогнозувати еволюцію суспільства, без чого практично неможливо прогнозувати стратегію розвитку підприємства. Ще родоначальники політичної економії, зокрема К. Маркс, стверджували, що управління соціально-економічним розвитком має базуватись на дії загальних законів природи [1, с. 37-90].

Нині дуже важливо підкреслити особливу роль кожної людини перш за все на підприємстві, де вона на своєму рівні включена в технологічний та управлінський процес, отже, впливає на загальний менеджмент підприємства, а опосередковано - 
на загальний менеджмент розвитку суспільства. Звідси виникає гостра потреба поєднати розуміння дії законів природи та управління взаємоузгодженою діяльністю різних систем, а саме людини, підприємства, суспільства на всіх рівнях їх діяльності. Як відомо, незнання закону, у цьому випадку - закону метасистеми, не звільняє від відповідальності. Людський фактор на будь-якому рівні управління має стати особливим фактором впливу на розвиток підприємства та інші соціально-економічні процеси.

Аналіз останніх досліджень і публікацій. Вивченню впливу нематеріальних факторів впливу на менеджмент систем присвячено достатньо наукових робіт зарубіжних та вітчизняних учених. Так, наприклад, вплив сучасних теорій менеджменту на розвиток персоналу вивчали Н.А. Пашкус, 3.А. Савельєва [2, с. 17-20]. Теоретичні аспекти філософії управління та системного моделювання розкриття потенціалу персоналу знайшли своє висвітлення у роботах В.А. Полякова [3, с. 47-54: 4, с. 94-120]. Окремим питанням розвитку людини в метасистемі планети приділяв увагу А.І. Суббето [5, с. 27-56]. Вплив сучасного суспільства на розвиток виробничих сил вивчав А.Н. Гумільов [6, с. 41-54]. Проблемам сучасних фінансово-економічних криз та шляхам і методам їх подолання присвятили свої дослідження А.А. Чухно [7, с. 72-84], В.С. Ціпуринда [8, с. 38-42].

Однак недосконало вивчено вплив закономірностей циклічного розвитку таких соціально-економічних систем, як суспільство, підприємство, вплив на розкриття творчого потенціалу персоналу, пріоритетів та цінностей кожної людини для розвитку внутрішнього й зовнішнього середовища підприємства, що обумовлюють розвиток суспільства та глобальної природної метасистеми, отже, впливають на соціально-економічні процеси.

Формулювання цілей статті. На основі викладеного можна сформулювати завдання дослідження, яке полягає у застосуванні інноваційного підходу до визначення пріоритетів та інструментів кадрового менеджменту в інноваційному розвитку підприємства та суспільства.

Подальше вивчення причинно-наслідкових взаємозв'язків розвитку людського потенціалу підприємства та його впливу на системні основи інноваційних процесів узгодженого розвитку та трансформаційних процесів в економічному просторі суспільства обумовило вибір мети дослідження.

Виклад основного матеріалу. Кожна людина має досягти поєднання розуміння причинно-наслідкових зв'язків узгодженого розвитку усіх систем від Макро- до Мікросвіту, зокрема підприємства, суспільства, в яких вона так чи інакше бере безпосередньо чи опосередковано участь. Людина і ніхто більше створює процес трансформації усіх без винятку систем, створюючи можливості для їх виходу на якісно новий рівень, формує різні ступені інноваційного вдосконалення систем, що відбувається за дією законів природи.

Оскільки управління (як упорядкування явищ) - це узгодженість розвитку усіх форм життєдіяльності, тобто різнорівневих систем, воно має будуватися на основі законів природи з урахуванням основних первинних трьох параметрів їх розвитку, таких як простір, час та енергія. Тільки за дією законів природи можна найбільш ефективно організувати простір життєдіяльності системи, вибрати найбільш оптимальний час іiї узгодженого розвитку у більших системах, у які вона входить, із найменшими витратами енергії.

Кожній системі дано життя, щоб організувати його найбільш ефективно, тобто за законами природи, а також надається для цього певна енергія. Коли в управлінні життєдіяльністю системи є певний конфлікт, то це означає, що енергія на їі життя витрачається всупереч дії законів природи, іï простір формується неправильно і не відповідає вимогам часу. Кожна система (людина, організація, підприємство, які є складовими частинами більшої системи - суспільства) має найбільш ефективно та 
узгоджено будувати свою життєдіяльність, враховуючи оптимальне співвідношення вищезгаданих трьох параметрів.

Якщо моделювати узгоджену діяльність підприємства у суспільстві на основі міждисциплінарного синтезу наук, то слід мати на увазі, що, як і будь-яка інша система, воно починає своє існування 3 дії Закону Боротьби і Єдності Протилежностей, або Закону Полярності. В природі цей закон породжує електричне поле. Це означає, що одночасно в системі розвивається полярно її внутрішній світ і зовнішній (для підприємства це його внутрішнє і зовнішнє середовище). Це приводить до появи першого типу управління, коли вибудовується зовнішній світ згідно з уявою внутрішнього. Цей тип управління завжди є авторитарним, який задля самозбереження нав'язує своє бачення первообразу або прототипу зовнішнього світу іншим системам.

На наступному етапі побудови системи зв'язків у ії зовнішньому середовищі вона вимушена будувати взаємоузгоджені зв'язки з іншою, у якої теж $є$ свій внутрішній світ і яка також вибудовує свої зв'язки із зовнішнім світом на основі свого первообразу або прототипу. Таким чином, обумовлено, що всі системи навчаються узгоджувати свої інтереси, покликання, місію, цілі, тому вступає в силу дія другого закону, а саме Закону Подібності і Спадкоємності (Повторення). Це приводить до появи другого типу управління, а саме демократичного, коли враховуються інтереси кожної системи, яка вступає у взаємозв'язки. В природі цей закон породжує на основі електричного поля магнітне поле (поле взаємного притяжіння, тяжіння). За певного узгодження покликань, цілей та інтересів дві системи обов'язково народжують третю, тобто спільне коло інтересів, бізнес, технологію спільної діяльності. Це вже дія третього закону, а саме Закону Збереження Енергії. Формується електромагнітне поле не тільки спільних цілей та інтересів, але й спільної взаємодії. При цьому зберігається дія попередніх Законів Полярності та Подібності. Це приводить до появи третього типу управління, а саме ліберального, коли ініціатива діяльності здебільшого (наприклад, на підприємстві) вже йде не від керівника, а від підлеглих. На рівні суспільства ініціатива повинна йти від народу, але від тих людей, які мають досвід і розуміння процесів управління та самоврядування.

Таким чином, у динаміці розвитку систем видно, що послідовно народжуються відповідні стилі (етапи) управління, а саме авторитарний, що пов'язаний $з$ диктатурою законодавця чи роботодавця (1-й закон), демократичний (2-й закон), що пов’язаний $з$ делегуванням частини своїх повноважень керівником. Як тільки виникають спільні узгоджені дії, наступає 3-й етап управління, а саме ліберальний (3-й закон). За дією цього закону розширюється простір спільної діяльності систем, для підприємств це $\epsilon$ розширенням сегменту ринку, а також розширенням та поглибленням процесу реалізації їх соціальної відповідальності у зовнішньому середовищі. Важливо відзначити, що ці етапи відображають індивідуальний розвиток, узгодженість взаємозв'язків та управління взаємодіями, що на четвертому етапі має досягти резонансу, трансформації систем за рахунок переходу з кількісних накопичень у якісні. Це вже дія 4-го Закону, а саме Закону Циклічності та партисипативного стиля управління (самоврядування). Перші 3 закони формують структуру системи, а 4-й закон формує динаміку її розвитку в часі, що потребує включення в систему управління представників усіх підсистем, тобто формування самоврядування вищого рівня на підприємстві, аналогічно у суспільстві, коли система досягає 4-го етапу та дії 4-го закону, коли формується повнота прояву системи у просторі та часі.

Існує 5-й етап, який відповідає 1-му етапу, але у новому циклі. Це вже дія п’ятого закону, а саме Закону Альтернативності (Свободи волі), який означає, що має відбуватися одночасне розширення внутрішне, а не тільки зовні, що означає поглиблення внутрішніх взаємозв'язків у системі, що невідворотно приводить до вдосконалення управління розвитком підсистем, тобто управління розвитком кожної людини. 
Нині в кожному суспільстві й на кожному підприємстві цей недолік щодо активного визволення творчих здібностей кожної людини ще має місце, тому світова соціально-економічна система все частіше потерпає від криз, при цьому загальновідомі цикли М. Кондратьєва все більш скорочуються.

Нині дуже важливо враховувати шостий закон, а саме Закон Ієрархічності, дія якого обумовлює взаємодію вертикалі узгодження цілей та інтересів усіх без винятку систем: від Макро- до Мікросвіту, де суспільство чи підприємство посідає своє важливе місце, тому якщо не узгоджуються покликання, цілі та інтереси усіх різнорівневих систем, то канал перетікання Енергії звужується і навіть блокується з усіма наслідками, що звідси випливають згідно із Законом Збереження Енергії, що призводить до криз.

Сьомий Закон - це Закон Цілеорієнтованості, дія якого для узгодженого розвитку суспільства, підприємства чи людини дуже важлива в розумінні ними того, в якому напрямі потрібно розвиватись: в екстенсивному чи інтенсивному; в напрямі аналізу, тобто інволюції чи еволюції; використання енергії роз'єднання чи синтезу, тобто об'єднання.

Отже, найважливішими пріоритетами та інструментами подальшого розвитку соціально-економічних систем, зокрема підприємств, є узгодження внутрішніх та зовнішніх процесів, де визначну роль відіграє творчий розвиток людини як першочастинки усіх інших систем. Якщо не буде досягнуто більш якісного внутрішнього управління розвитком людини, то поступово припиниться зовнішнє, оскільки вступає в дію знову Закон Полярності (новий етап), що призведе до напруги і криз. Для цього потрібна особлива рівновага поглиблення внутрішнього життя кожної системи та ії̈ зовнішньої взаємодії. Це стосується перш за все створення відповідних умов на підприємстві та суспільстві для прояву кожної людини відповідно до ії покликання, що реалізується в узгодженому розвитку усіх соціально-економічних систем. Загальновідомо, що наскільки людина управляє своїм внутрішнім світом, настільки широко та гармонійно буде вибудовуватися простір ії взаємовідносин зовні.

Це повною мірою стосується підприємства, у програмі розвитку якого мають проявлятися динамічно залежно від етапу розвитку й професійної та управлінської підготовки людей 4 стилі управління, що забезпечить йому ефективність, рівновагу та успішність. Таке підприємство здатне формувати новий простір свого прояву в більш стислий період часу та продукувати новизну й ефективність, входити в новий простір взаємовідносин не конфліктно, а з урахуванням інтересів кожного суб'єкта в ньому.

Звідки беруться талановиті керівники у суспільстві? Це ті керівники, які пройшли відповідні ступені управлінського досвіду на шляху керівництва різними системами на підприємстві, тому кожне підприємство, як і суспільство, має бути зацікавлене у вирощуванні досвідчених керівників, здатних вирішувати будь-які проблеми в управлінні. Однак для цього має бути налагоджена системна, покрокова й комплексна підготовка керівника, що охоплює досвід управління не тільки виробничий, але й управління соціальними та територіальними системами і об'єднаннями (рис. 1).

При цьому досвід виробничого самоврядування набувається у сфері виробництва на різних рівнях управління підприємством та побудові системи управління за участю в ній кожного працівника, а також співволодіння ресурсами підприємства на його рівні.

Досвід територіального самоврядування набувається у сфері управління розширенням ринку підприємства, досвіду побудови його філіалів та управління ними тощо. Досвід соціального самоврядування набувається у сфері роботи профспілок на підприємстві.

Отже, оскільки підприємство є первинною ланкою, що відображає устрій суспільства 3 його трьома основними гілками влади 3 набуттям відповідного досвіду управ- 
ління, то кожний керівник так чи інакше для набуття повноти цього досвіду має бути знайомий з відповідним управлінням виробничого, соціального й територіального характеру на самому підприємстві. Так чи інакше кожний керівник на своєму рівні має включатись у вирішення питань соціального та територіального життя підприємства. Це може бути основою досвіду для успішного керівництва за межами підприємства, наприклад, в управлінні територіальними громадами чи системами соціального характеру.

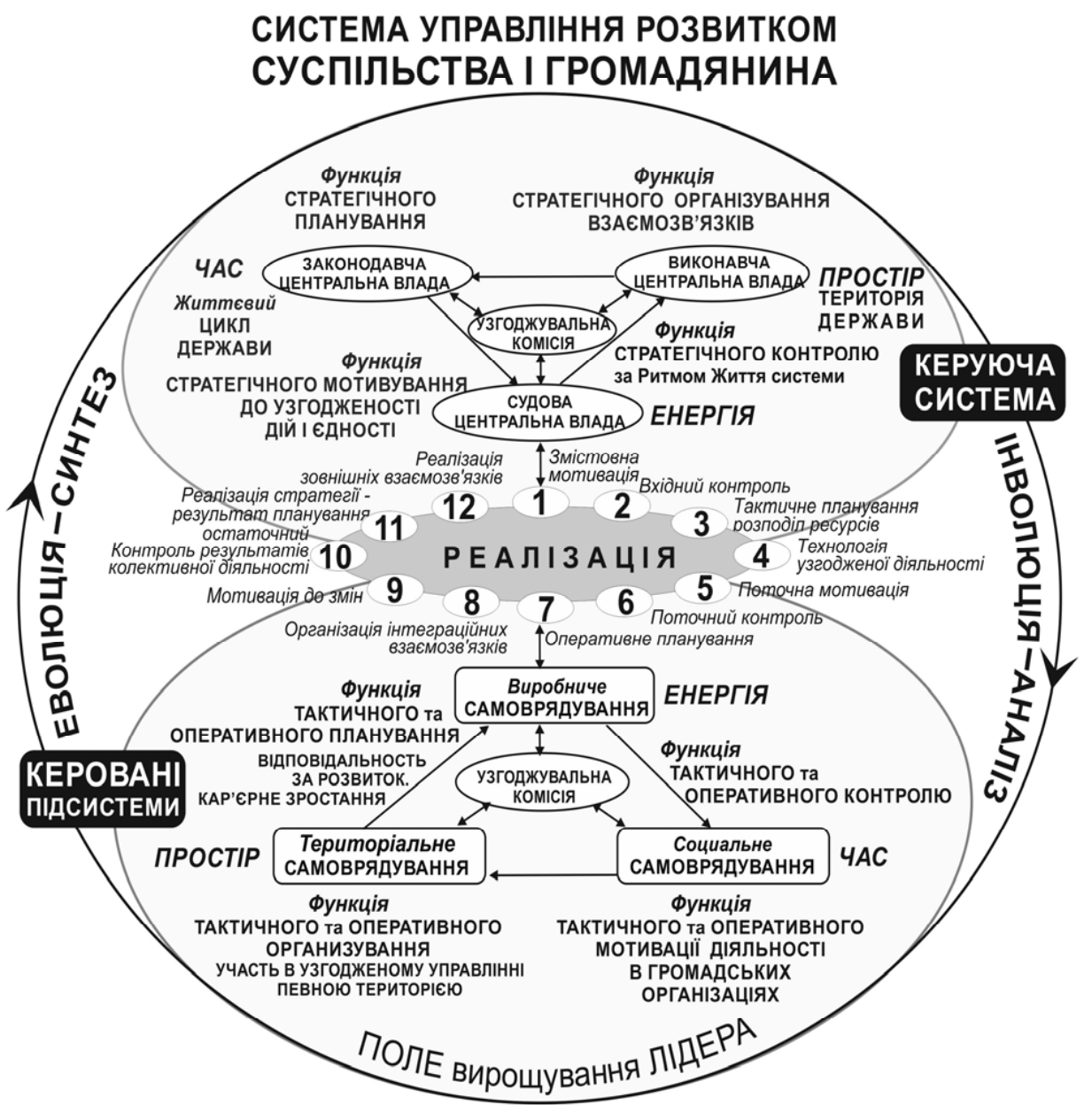

Рис. 1. Система причинно-наслідкового взаємозв'язку трьох гілок влади та комплексної підготовки керівника

Потрійність комплексу такого управління відображається в трьох гілках управління підприємством, де законодавчою владою є збори акціонерів, якщо підприємство $\epsilon$ акціонерним товариством, виконавчою владою $є$ дирекція, а узгоджувальною - профспілковий комітет. Така система повністю відповідає трьом гілкам влади в суспільстві, а саме законодавчій, що вирішується Верховною Радою; виконавчій, що вирішується урядом; узгоджувальній, що вирішується судовою системою.

Ця система потрійності повторення досвіду управління як на низових рівнях, так і на рівні суспільства вирішується повторенням чотирьох основних функцій управ- 
ління, а саме плануванням, організуванням, мотивуванням та контролюванням, тому поетапне поєднання потрійності узгодженого досвіду стратегічного, тактичного й оперативного видів планування, організування, мотивування та контролювання 3 регулюванням має на меті досягнення ідеального управлінського циклу у 12 етапівдетермінант.

Коли підприємство займається таким внутрішнім вдосконаленням, то воно не конкурує з іншими, а шукає нові можливості свого розвитку та реалізації на ринку. Дослідження, які проведені на підприємствах різних форм власності в Україні, Росії та Польщі з участю авторів, виявили ці особливості й проблеми в розвитку цієї тенденції. Наприклад, за участю авторів таким чином була перебудована система управління на підприємстві «Ласкомекс» (м. Лодзь, Польща), що привело не тільки до підвищення ефективності діяльності підприємства, але й до формування нової системи якості як такої, що визнана Свропейськими нормами.

Підсумовуючи результати аналізу ефективності діяльності підприємств, зауважимо, що чим вище рівень узгодженості комплексу цих трьох складових елементів підприємства, тим більше у підприємства конкурентних переваг для здійснення ефективної діяльності й розвитку, тим більше переваг у підготовці керівного складу підприємства, з якого виходять кращі керівники на рівні управління суспільством.

Висновки. 3 наведеного вище можна зробити такі висновки:

1. Для підготовки ефективного керівника необхідна його участь у накопиченні досвіду управління підприємством у потрійності виробничого, соціального та територіального характеру на кожному рівні управлінського циклу підприємства та його підрозділів. Таким чином, управлінський цикл має 12 кроків-детермінант, що дає змогу досягти повноти досвіду планування, організування, мотивування та контролю в управлінні.

2. Така взаємоузгоджувальна система управлінського циклу дає змогу ефективно поєднувати керівнику будь-якого рівня свою роботу в трьох релятивних параметрах, а саме в часі, просторі та ефективному розпорядженні енергією (усіма видами ресурсів).

3. Ця система причинно-наслідкових взаємозв'язків дає змогу у такому полі вирощування лідера готувати керівний склад в ефективному управлінні системами будьякого рівня та готувати для суспільства не тільки керівників, але й громадян високої свідомості.

Отже, кожне підприємство має бути відкритою системою, яка невпинно саморозвивається і для досягнення ефективного розвитку покладається на:

- структурно-динамічну систему узгодженого розвитку усіх складових елементів і систем;

- універсальну систему управління, яка забезпечує його оптимальну діяльність на всіх етапах розвитку (структуроутворення, розвиток горизонтальних зв'язків між підсистемами, управління ієрархічними зв'язками та трансформаційним виходом на більш високий якісний рівень розвитку);

- систему управління і самоврядування, які розкривають ініціативу та відповідальність не тільки керівника, але й кожної людини за розвиток підприємства; при цьому накопичується керівниками різних рівнів комплексний досвід управління на підприємстві (виробниче, територіальне й соціальне самоврядування).

\section{Список використаних джерел:}

1. Маркс К., Энгельс Ф. Сочинения. 2-е изд. Москва : Политиздат, 1961. Т. 23.712 с.

2. Пашкус Н.А., Пашкус В.Ю., Савельева 3.А. Современные теории управления: теории менеджмента на пороге XXI века. Санкт-Петербург : Сентябрь, 2002. 268 с.

3. Поляков В.А. Универсальная экономическая теория. Организационный механизм управления. Москва : Новый центр, 2014. 192 с. 
4. Поляков В.А. Философия управления. Москва : Новый центр, 2016. 188 с. $538 \mathrm{c}$.

5. Субетто А.И. Ноосферизм. Введение в ноосферизм. Санкт-Петербург : Астерион, 2003.

6. Гумилев Л.Н. Этногенез и биосфера Земли. Москва : Кристалл, 2001. 638 с.

7. Чухно А.А. Сучасна фінансово-економічна криза: природа, шляхи і методи її подолання. Економіка України. 2010. № 1. С. 4-16.

\section{References:}

1. Marks K., Engels F. (1961) Sochinenia [Compositions]. Moscow: Political Publishing House. (in Russian)

2. Pashkus N.A. (2002) Sovremennie theorii upravlenia: theorii menedgmenta na poroge XXI veka [The Modern theories rules: management theories on the threshold of the XXI century]. Saint-Petersburg: September. (in Russian)

3. Polakov V.A. (2014) Universalnaya economicheskaya theoria. Organizatzionniy mechanism upravlenia [Universal economic theory. Organizatsional mechanism]. Moscow: New center. (in Russian)

4. Polakov V.A. (2016) Philosophya upravlenia [Management philosophy]. Moscow: New center. (in Russian)

5. Subetto A.I. (2003) Noosferizm. Vvedenie v noosferizm [Noosferizm. Introduction is to noosferizm]. Saint-Petersburg: Asterion. (in Russian)

6. Gumilev L.N. (2001) Etnogenez I biosfera Zemli [Etnogenez and biosphere of Earth]. Moscow: Crystal. (in Russian)

7. Chuhno A.A. (2010) Suchasna finansovo-ecnomichna kriza: priroda, shlychi I metody podolannia [Modern financially is an economic crisis: nature, ways and methods of her overcoming]. Ukrainian economic Journal, vol. 1, no. 1, pp. 4-16. 